\title{
Analisa SWOT Manajemen Pendidikan di SMK Maarif 1 Kebumen
}

\author{
Agus Salim Chamidi, \\ IAINU Kebumen \\ aschamidi@yahoo.co.id \\ Mahasiswa S1 MPI IAINU Kebumen \\ Atikhah Lestari, Eka Ariskawanti, Kuni Dwi Hidayati, \\ Nuni Nur Baety H, Nur Rohmah, Rosyidah, Tata Istikomah
}

\begin{abstract}
This article is the result of lecturer-student collaborative research in curricular activities of the Professional Training Program (PLP)/Internship I on S1 Islamic Education Management Study Program. The research objective is to find out the management of education in schools. The formulation of the problem is (1)how is the management of education in 4 fields in SMK Maarif 1 Kebumen in 4 fields of education management ?, and (2)what are the obstacles and obstacles in their implementation, and what is the solution? It is a qualitative research with data collection techniques are interviews, observation, and documentation. Its informants are the Principal of SMK Maarif 1 Kebumen, the Deputy Head of SMK Maarif 1 Kebumen, and a number of people related to the research topic. Research analysis using the SWOT analysis model. The research was conducted in July-August 2019. The results of the research are: (1)Management of Curriculum and Learning at SMK Ma'arif 1 Kebumen is in accordance with BSNP standards, (2)Management of Students at SMK Ma'arif 1 Kebumen is of good quality with proven evidence of increasing participants students who have carved achievements in both academic and non-academic fields, (3)Management of Educators and Education Personnel at SMK Ma'arif 1 Kebumen is sufficient with indicators of educators and education staff who are already competent and certified in their fields, and they also prove their abilities by making them Student achievement and ethics, (4)Management of Industrial Relations and Public
\end{abstract}


Relations at SMK Ma'arif 1 Kebumen is already good with the proven number of students who are absorbed by the business world and industry (DUDI).

Keywords: Education Management, SMK Maarif 1 Kebumen.

\begin{abstract}
Abstrak
Artikel ini hasil riset kolaboratif dosen-mahasiswa dalam kegiatan kurikuler Program Latihan Profesi (PLP)/Magang I Program Studi S1Manajemen Pendidikan Islam. Tujuan riset adalah mengetahui penyelenggaraan manajemen pendidikan di sekolah. Rumusan masalahnya adalah (1)bagaimana penyelenggaraan manajemen pendidikan pada 4 bidang di SMK Maarif 1 Kebumen pada 4 bidang manajemen pendidikan?, dan (2)apa saja kendala dan hambatan pelaksanaannya, serta bagaimana solusinya? Riset bersifat kualitatif dengan teknik pengumpulan data adalah wawancara, observasi, dan dokumentasi. Informan riset adalah Kepala SMK Maarif 1 Kebumen, Wakil Kepala SMK Maarif 1 Kebumen, dan sejumlah orang terkait pokok riset. Analisa riset menggunakan model analisa SWOT. Riset dilakukan pada Juli-Agustus 2019. Hasil riset adalah: (1) Manajemen Kurikulum dan Pembelajaran di SMK Ma'arif 1 Kebumen sudah sesuai standar BSNP, (2)Manajemen Peserta Didik di SMK Ma'arif 1 Kebumen sudah berkualitas dengan dibuktikannya meningkatnya peserta didik yang telah mengukir prestasi di bidang akademik maupun non akademik, (3)Manajemen Pendidik dan Tenaga Kependidikan di SMK Ma'arif 1 Kebumen sudah memadai dengan indikator pendidik dan tenaga kependidikan yang sudah kompeten dan bersertifikasi di bidangnya, dan mereka juga membuktikan kemampuannya dengan menjadikan peserta didik berprestasi dan beretika, (4)Manajemen Hubungan Industri dan Hubungan Masyarakat di SMK Ma'arif 1 Kebumen sudah baik dengan dibuktikannya banyaknya peseta didik yang diserap oleh dunia usadan industri (DUDI).
\end{abstract}

Katakunci: Manajemen Pendidikan, SMK Maarif 1 Kebumen.

\title{
Pendahuluan
}


SMK Maarif 1 Kebumen merupakan sekolah menengah atas kejuruan pertama yang didirikan oleh Lembaga pendidikan Maarif NU Kebumen sejak 1990. Tahun 2007 sekolah ini menggunakan manajemen ISO 9001:2000 dan SMM 9001:2008. Tahun 2008 sekolah ini mendapatkan kepercayaan pemerintah menjadi sekolah Rintisan Sekolah Berstandar Internasional (RSBI). Yang menarik, sekolah ini sekarang tidak lagi menggunakan manajemen ISO, dan manajemennya berbasis sekolah.

Beberapa riset sebelumnya , misalnya riset Luki Eko Cahyono, dkk. ${ }^{1}$ di SMPN 2 Madiun yang menggunakan analisis SWOT untuk 8 SNP. Hasil risetnya adalah, bahwa kekuatan lebih besar daripada kelemahan dan peluang lebih besar dari ancaman, dan SNP telah memenuhi dengan hasil akreditasi A. Berbeda dengan riset Luki dkk., riset ini dilakukan di satuan pendidikan SMK dan fokus pada 4 bidang. Riset lain adalah riset Iskandar Putong ${ }^{2}$, yang hasilnya adalah penggunaan analisa SWOT akan mampu membantu karyawan melakukan analisis dan disiplin. Berbeda dengan Putong, riset ini sebatas untuk mengetahui pelaksanaannya dan mengetahui solusi yang diambil saat mengahdapi hambatan dan kendala. Adapun tulisan David Wijaya mencoba fokus terkait manajemen SDM Pendidikan berbasis kompetensi guru ${ }^{3}$. Tulisan David menyimpulkan bahwa manajemen SDM berbasis kompetensi guru perlu terintegrasi, dan kepentingan integrasi ini memerlukan sosok kepala sekolah berperan secara strategis untuk peningkatan mutu sekolah. Berbeda dengan riset David, riset ini hanya membatasi pada upaya kepala sekolah dalam menyelesaikan kendala dan hambatan yang muncul saja.

Manajemen pendidikan Islam merupakan perencanaan, pengorganisasian, pelaksanaan, dan pengawasan di dalam lembaga pendidikan Islam untuk mencapai tujuan pendidikan Islam berupa pembangunan sumber daya manusia,

\footnotetext{
${ }^{1}$ Luki Eko Cahyono, Satrijo Budiwibowo, Juli Murwani, “Analisis penerapan 8 Standar Nasional Pendidikan pada SMP Negeri 2 Dolopo Kabupaten Madiun”, Jurnal Assets, Volume 4, Nomor 2, Oktober 2015, hal. 99-105.

${ }^{2}$ Iskandar Putong, "Teknik Pemanfaatan Analisis SWOT Tanpa Skala Industri”, Jurnal Ekonomi dan Bisnis, Nomor 2, Jilid 8, Tahun 2003, hal. 65-71.

${ }^{3}$ David Wijaya, "Manajemen Sumber Daya Manusia Penedidikan Berbasis Kompetensi Guru dalam Rangka Membangun Keunggulan Bersaing Sekolah", Jurnal Pendidikan Penabur, Nomor 12,Tahun ke-8, Juni 2009, hal. 69-86.
} 
insan kamil, dengan mendasar pada nilai-nilai keislaman yang bersumber pada Al-Qur'an dan Al-Hadits dengan memberdayakan setiap sumber daya yang ada secara efektif, efisien dan produktif, agar mencapai kebahagiaan dunia dan akhirat. ${ }^{4}$ SMK Maarif 1 Kebumen sebagai lembaga pendidikan di bawah LP Maarif NU yang tentunya menyelenggarakan model manajemen pendidikan sesuai dengan nilai-nilai keIslaman khas. Oleh karenanya sebuah riset menjadi penting untuk mengetahui pelaksanaan manajemen pendidikan di sekolah ini, dan untuk mengetahui kendala dan hambatan yang muncul dalam pelaksanaan manajemennya.

Sebagaimana lembaga pendidikan setingkat lainnya, SMK Maarif 1 Kebumen juga melaksanakan 8 Standar Nasional Pendidikan (SNP) sebagaimana amanat Undang-Undang Nomor 20 Tahun 2003 tentang Sistem Pendidikan Nasional (Sisdiknas) Bab IX tentang SNP. 8 SNP ini terdiri dari standar isi, standar proses pembelajaran, standar kompetensi lulusan, standar pendidik dan tenaga kependidikan, standar sarana dan prasarana, standar pengelolaan, standar pembiayaan/biaya operasi, dan standar penilaian pendidikan ${ }^{5}$. Hanya saja riset ini lebih menfokuskan pada 4 bidang yaitu, manajemen kurikulum dan pembelajaran, manajemen pendidik dan tenaga kependidikan, manajemen peserta didik, dan manajemen hubungan industri dan masyarakat. Adapun rumusan masalah riset ini adalah (1)bagaimana manajemen di SMK Maarif 1 Kebumen terkait dengan manajemen kurikulum dan pembelajaran, manajemen pendidik dan tenaga kependidikan, manajemen peserta didik, dan manajemen hubungan industry dan masyarakat?, dan (2)apa saja kendala dan hambatan yang muncul dalam penyelenggaraan keempat manajemen tersebut?, serta bagaimana solusi yang diambil oleh kepala sekolah sebagai pimpinan di SMK Maarif 1 Kebumen?

\section{Metode}

\footnotetext{
${ }^{4}$ Agus Salim Chamidi dan Tutik Rodhiana, "Upaya Penguatan Manajemen Pendidikan Baca Tulis Al-Qur'an (BTQ) Studi Kasus di Sekolah Dasar Negeri 1 Kutowinangun”, Jurnal Cakrawala, Volume 2, Nomor 1, Tahun 2018, hal.1-16.

${ }^{5}$ Undang Undang Nomor 20 Tahun 2003 tentang Sistem pendidikan Nasional, Bab IX, Pasal 35. Lihat juga Peraturan Menteri Pendidikan dan Kebudayaan RI Nomor 34 Tahun 2018 tentang Standar Nasional Pendidikan Sekolah Menengah Kejuruan/Madrasah Aliyah Kejuruan.
} 
Riset bersifat kualitatif. Permasalahan ini akan dicari jawabannya melalui teknik wawancara, observasi, dan dokumentasi. Informan riset adalah Kepala SMK Maarif 1 Kebumen, Wakil-wakil Kepal SMK Maarif 1 Kebumen, dan sejumlah orang terkait. Data riset akan dianalisa menggunakan model analisa SWOT (Strength, Weakness, Opportunity, Threat). Menurut John M. Bryson dalam Nur Kholis ${ }^{6}$, analisa SWOT, adalah suatu analisis lingkungan yang berdasarkan pada kondisi, situasi, keadaan, peristiwa, dan pengaruh di dalam dan di sekitar organisasi yang berdampak pada kehidupan organisasi yang meliputi kekuatan, kelemahan, peluang, dan tantangan. Sedangkan menurut Boseman dalam Syaifudin Sagala $^{7}$, analisis SWOT adalah salah satu tahap dalam manajemen strategi yang merupakan pendekatan analisis lingkungan. Analisis SWOT merupakan alat untuk mengetahui atau menganalisis lingkungan internal maupun eksternal suatu lembaga.

Riset bersifat kualitatif dan hasil analisa akan dijelaskan dengan deskriptif analitik. Riset dilakukan pada Agustus 2019 melalui kerja kelompok mahasiswa dengan bimbingan dosen dalam kegiatan kurikuler Program Latihan Profesi (PLP)/Magang I Program Studi S1 Manajemen Pendidikan Islam IAINU Kebumen.

\section{Hasil dan Pembahasan}

\section{A. Manajemen Kurikulum dan Pembelajaran}

Kurikulum merupakan komponen terpenting dalam proses pembelajaran. Kurikulum digunakan sebagai acuan dalam proses pembelajaran. Kurikulum yang digunakan di SMK Ma'arif 1 Kebumen merupakan Kurikulum 2013 yang direvisi dan disesuaikan dengan sekolah yang dikenal sebagai Kurikulum Tingkat Satuan Pendidikan 2013.

Penyusunan kurikulum dilaksanakan sebelum tahun ajaran baru dimulai. Kegiatan penyusunan kurikulum tersebut diawali dengan workshop atau IHT (In

\footnotetext{
${ }^{6}$ Nur Kholis. Manajemen Strategi Pendidikan. Cet.1, (Surabaya: CV. Cahaya Intan XII). 2014, hal. 40

7 Syaifudin Sagala. Manajemen Strategi Dalam Peningkatan Mutu Pendidikan. (Bandung: Alfabeta). 2010, hal. 140
} 
House Training), yang diikuti oleh Kepala Sekolah, Wakil-wakil Kepala Sekolah, dan semua guru mata pelajaran, dengan melibatkan pihak industri (DUDI). Dalam kegiatan workshop ini, seluruh peserta mendapatkan pembekalan materi terkait penyusunan kurikulum sesuai Permendikbud Nomor 20 Tahun 2016 tentang Standar Kompetensi Lulusan Pendidikan Dasar dan Menengah (SKL), termasuk juga SKKNI (Standar Kompetensi Kerja Nasional Indonesia).

Penyusunan kurikulum di SMK Ma'arif 1 Kebumen dilakukan oleh tim pengembang kurikulum yang terdiri dari Wakil Kepala Sekolah Bidang Kurikulum, beserta stafnya, kepala jurusan dan ketua kelompok kerja tiap mata pelajaran. Tim ini nantinya akan menghasilkan buku kurikulum. Buku kurikulum ini akan menjadi dasar penyusunan silabus, program tahunan (prota), program semester (promes) dan Rencana Pelaksanaan Pembelajaran (RPP) yang di dalamnya terdapat Kompetensi Inti (KI), Kompetensi Dasar (KD), indikator hasil belajar, dan Penilaian Berbasis Kelas (PBK). Dalam buku kurikulum ini juga terdapat muatan lokal Bahasa Jawa dan muatan identitas Ke-NU-an dan AlQur'an.

Rencana Pelaksanaan Pembelajaran (RPP) dijadikan sebagai dasar pelaksanaan pembelajaran oleh guru. Proses pembelajaran berlangsung sesuai dengan RPP. Selain menyusun RPP, Tim Kurikulum juga membuat Kalender Pembelajaran untuk mendapatkan dan mengatur waktu yang efektif dan membuat membuat Jadwal Mengajar di SMK Ma'arif 1 Kebumen. Pembelajaran bersifat interaktif dan inovatif, dengan media pembelajaran yang mendukung. Selain itu, guru juga akan memberikan ruang untuk siswa bereksplorasi dan elaborasi untuk mengembangkan kemampuan siswa.

Guru memberikan tugas kepada siswa baik tugas terstruktur, tidak terstruktur dan tugas mandiri. Tugas tersebut sebagai bahan penilaian kemampuan siswa oleh guru. Selain tugas terdapat juga ujian penilaian tengah semester dan penilaian semester. Setelah proses pembelajaran selesai dilaksanakan, guru melakukan evaluasi dari pemahaman yang diperoleh oleh siswa. Selain penilaian pembelajaran, guru juga melakukan evaluasi dari sikap siswa yang dapat diketahui dari lembar penilaian sikap yang di miliki oleh tiap guru mata pelajaran. 
Selain kurikulum yang bersifat akademik dan terstruktur, terdapat juga kurikulum yang merupakan kegiatan pembiasaan bagi siswa, guru dan tenaga kependidikan yaitu kegiatan yasinan setiap hari jum'at untuk siswa dan kegiatan mujahadah setiap pagi untuk guru dan karyawan. Selain itu terdapat juga English Conversation yang diperuntukan untuk seluruh siswa dengan sistem bergilir.

Berikut alur skema pendelegasian tugas Manajemen Kurikulum di SMK Ma'arif 1 Kebumen :

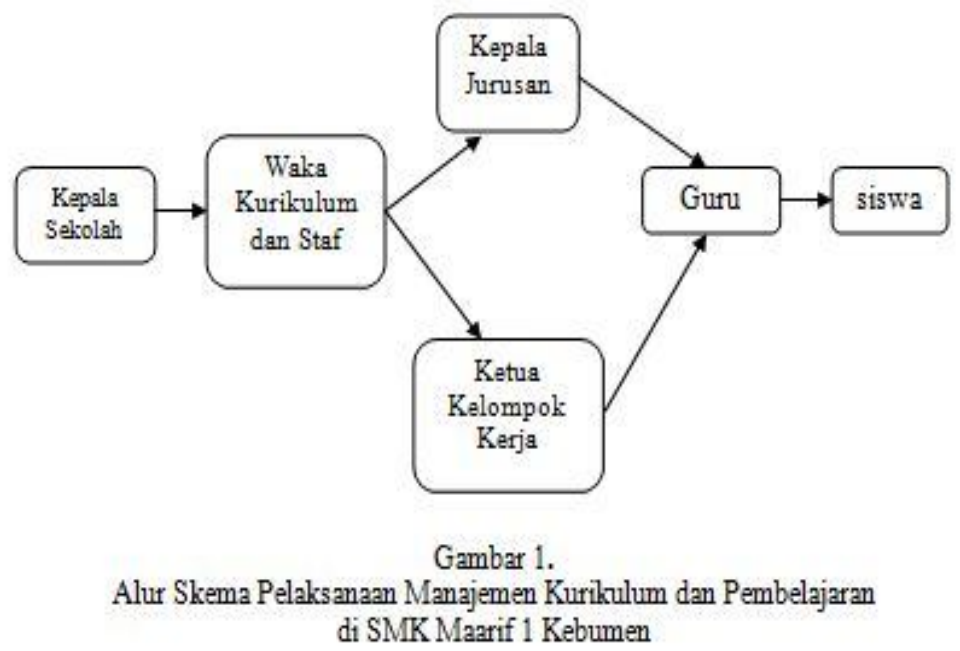

Dari skema di atas dapat diketahui bahwa pelaksanaan kurikulum diawali dari kepala sekolah yang mendelegasikan kepada waka bidang kurikulum yang kemudian dari waka bidang kurikulum mendelegasikan tugas kepada kepala jurusan yang selanjutnya didelegasikan kepada ketua kelompok kerja. Dari ketua kelompok kerja akan mendelegasikan lagi kepada masing-masing guru mata pelajaran yang akan melaksanakannya bersama siswa.

Semua pelaksanaan kegiatan kurikulum dan pembelajaran akan disupervisi dan di monitoring oleh kepala sekolah maupun wakil kepala sekolah setiap minggunya. Supervisi ini dilakukan baik di kampus I sebagai tempat pembelajaran teori dan kampus II sebagai tempat praktek. Selain setiap minggu, supervisi juga dilakukan setiap harinya oleh kepala jurusan masing-masing. 
Pelaksanaan kurikulum didukung oleh beberapa faktor pendukung, diantaranya sebagai berikut :

a. Kemudahan mendapatkan informasi mengenai pembaharuan kurikulum

b. Mengevaluasi kurikulum secara rutin, setiap sebelum awal tahun pembelajaran.

c. Kerja sama tim yang solid.

Seluruh komponen sekolah sudah mendukung penyelenggaraan manajemen kurikulum dan pembelajaran di SMK Maarif 1 Kebumen. Hanya saja, menurut Muhtarudin Wakil Kepala Bidang Kurikulum, yang masih menjadi kendala/penghambat adalah terlambatnya guru dalam pengumpulan rencana pelaksanaan pembelajaran (RPP). Solusinya kepala sekolah melalui wakil kepala kurikulum mengingatkan para guru untuk segera mengumpulkan RPP, membuat deadline pengumpulan RPP, dan memberikan catatan khusus bagi guru yang terlambat. Solusi ini cukup jitu menyelesaikan masalah.

\section{B. Manajemen Peserta Didik}

\section{Siswa}

Siswa SMK Ma'arif 1 Kebumen tahun pelajaran 2019/2020 berjumlah 2.322 orang dan terbagi dalam kelas X, XI, dan kelas XII. Kelas X sebanyak 731 siswa, laki-laki 486 siswa dan perempuan 245 siswa, yang terbagi atas 22 Rombongan Belajar (Rombel), terdiri atas 2 Rombel Teknik Audio Video (TAV), 2 Rombel Teknik Elektro Industri (TEI), 11 Rombel Teknik Kendaraan Ringan (TKRO), 5 Rombel Multimedia, dan 2 Rombel Perhotelan.

Sedangkan jumlah siswa kelas XI sebanyak 691 siswa, laki-laki 463 siswa, perempuan 228 siswa, yang memiliki 20 Rombel terdiri atas 2 Rombel Teknik Audio Video (TAV), 2 Rombel Teknik Elektro Industri (TEI), 10 Rombel Teknik Kendaraan Ringan (TKRO), 4 Rombel Multimedia, dan 2 Rombel Perhotelan.

Kelas XII memiliki 900 siswa, laki-laki 616 siswa, perempuan 284 siswa, yang memiliki 27 Rombel dengan perincian 2 Rombel Teknik Audio Video (TAV), 4 Rombel Teknik Elektro Industri (TEI), 14 Rombel Teknik Kendaraan Ringan (TKRO), 5 Rombel Multimedia, dan 2 Rombel Perhotelan. 


\section{Proses Penerimaan Peserta Didik}

Penerimaan peserta didik baru (PPDB) merupakan salah satu kegiatan sekolah yang termasuk dalam manajemen kesiswaan. PPDB dilakukan setiap awal tahun pelajaran dengan proses: (1)pembentukan panitia sosialisasi terkait pendidikan universal (pendidikan wajib belajar 12 tahun dan mengenalkan profil SMK Ma'arif 1 Kebumen, (2)pembentukan Panitia Penerimaan Peserta Didik Baru, dan (3)menyusun target penerimaan peserta didik baru. Urusan kesiswaan ini ditangani oleh Wakil Kepala Sekolah Bidang Kesiswaan. Selain itu mereka juga berwenang mengelola penerimaan peserta didik baru dengan kualifikasi: (1)calon peserta didik tidak bermasalah, (2)calon peserta didik bukan siswa pindahan, (3)calon peserta didik harus beraliran NU (Ahluss sunnah wal jama'ah).

Pendaftaran dilakukan secara manual dengan mengisi brosur. Kejuruan dilaksanakan pada saat pendaftaran dengan disertai surat kemantapan pemilihan jurusan. Pertimbangan menyertakan surat kemantapan pemilihan jurusan karena evaluasi dari program yang lalu bahwa ketika peserta didik yang sudah diterima banyak yang meminta untuk pindah jurusan. Pemindahan jurusan bagi peserta didik masih diperbolehkan dalam kurun waktu 1 minggu setelah proses belajar mengajar sudah efektif. Dalam hal ini kejuruan yang ada di SMK Ma'arif 1 Kebumen diantaranya: Teknik Audio Video (TAV), Teknik Elektro Industri (TEI), Teknik Kendaraan Ringan (TKRO), Multimedia, dan Perhotelan.

Proses penerimaan peserta didik baru yang ada di SMK Ma'rif 1 Kebumen dilaksanakan melalui tes wawancara yang meliputi: asal sekolah, minat sekolah, alamat dan bertempat tinggal dengan siapa, pekerjaan orang tua, pendapatan orang tua dalam setiap bulanya, tidak bertindik, tidak bertato, serta penilaian sikap.

Proses penerimaan peserta didik baru dilakukan dalam 1 hari (one day, one service) dengan mempertimbangkan keseriusan peserta didik untuk bergabung di SMK Ma'arif 1 Kebumen. Setelah melakukan tes wawancara peserta didik 
langsung mendapatkan hasilnya (diterima/tidak). Bagi peserta didik yang dinyatakan diterima, maka peserta didik baru wajib melakukan daftar ulang yang diberi kurun waktu selama 1 minggu. Setelah melakukan daftar ulang peserta didik baru melakukan Masa Pengenalan Lingkungan Sekolah (MLPS). Dalam Masa Pengenalan Lingkungan Sekolah (MLPS) yang sudah ditetapkan kurun waktunya oleh lembaga pendidikan SMK Ma'arif 1 Kebumen, peserta didik baru diharapkan mampu mengenali profil SMK Ma'arif 1 Kebumen dan berbagai macam ekstra kulikuler yang ada, mengenalkan guru-guru dan karyawan SMK Ma'arif 1 Kebumen, Kurikulum yang diterapkan, Mengenalkan jurusan yang ada, dan mengajak keliling peserta didik baru untuk mengetahui sarana dan prasarana yang ada termasuk gedung praktik yang berada di Jalan HM Sarbini 191 Kebumen.

Sejak awal, sekolah ini juga sudah mengatur bidang kesiswaan yang menyangkut tatacara pakaian/seragam, potongan rambut, dan budaya $7 \mathrm{~K}$ (Kebersihan, Keamanan, Ketertiban, Kekeluargaan, Kesehatan, Kerindangan dan Kenyamanan Sekolah) melalui Peserta Didik. Sekolah ini juga memberikan beasiswa dengan sejumlah kriteria. Mulai tahun ini, sekolah ini membuat rencana pembagian kelas unggulan yang ditempatkan di kelas A di setiap jurusan atau prodi.

\section{Monitoring dan Evaluasi Hasil Belajar Peserta Didik}

Dalam meningkatkan kualitas mutu pendidikan dan monitoring peserta didik, Bidang Kesiswaan melalui Bagian Bimbingan dan Konseling (BK) bekerjasama dengan Pembina OSIS melakukan pemantauan operasi handphone yang tidak terjadwalkan, selain soal kerapihan, kedisplinan, dan peribadatan Islam. Peningkatan dan evaluasi hasil belajar menjadi tanggung jawab guru mata pelajaran. Pengevaluasian peserta didik dilakukan dengan tiga tahap, seperti: (1)evaluasi harian, yang berupa wawancara atau kuis tanya jawab yang diberikan kepada beberapa peserta didik sesuai dengan mata pelajaranya, (2)evaluasi mingguan berupa soal tertulis kemudian para peserta didik diharuskan mengerjakan soal dari guru mapelnya. Evaluasi ini dilakukan ketika sudah melakukan 3x pertemuan, dan (3)evaluasi bulanan (triwulan, semesteran) berupa 
evaluasi yang terstruktur dan terjadwalkan, termasuk UTS dan UAS. Kemudian untuk kelulusan peserta didik, maka ujian nasioanal (UN) akan dilaksanakan menjelang akhir periode menjadi peserta didik. Akan tetapi hasil UN tidak mempengaruhi kelulusan, karena fungsi ujian nasional digunakan sebagai pemetaan nasional.

\section{Pengelolaan Alumni SMK Ma'arif 1 Kebumen}

Dalam mempererat tali silaturahmi antar pendidik dan tenaga kependidikan dengan para alumni SMK Ma'arif 1 Kebumen membentuk ikatan yang bernamakan FORZA (Forum Alumni SMK Ma'arif 1 Kebumen). Salah satu pemanfaatan dari ikatan FORZA tersebut yaitu digunakan untuk saling berkoordinasi untuk melakukan kegiatan rutinan setiap tahunnya yang melibatkan beberapa tenaga pendidik maupun kependidikan SMK Ma'arif 1 Kebumen seperti: (1)melaksanakan kegiatan buka bersama alumni (setiap H-3 Idul Fitri), (2)alumni berpartisipasi dalam kegiatan santunan anak yatim piatu setiap tanggal 10 Muharram, (3)kunjungan pihak sekolah ke berbagai tempat penempatan kerja alumni SMK Ma'arif 1 Kebumen untuk meninjau keberhasilan lulusan.

Berikut skema pendelegasian tugas manajemen kesiswaan di SMK Ma'arif 1 Kebumen : 


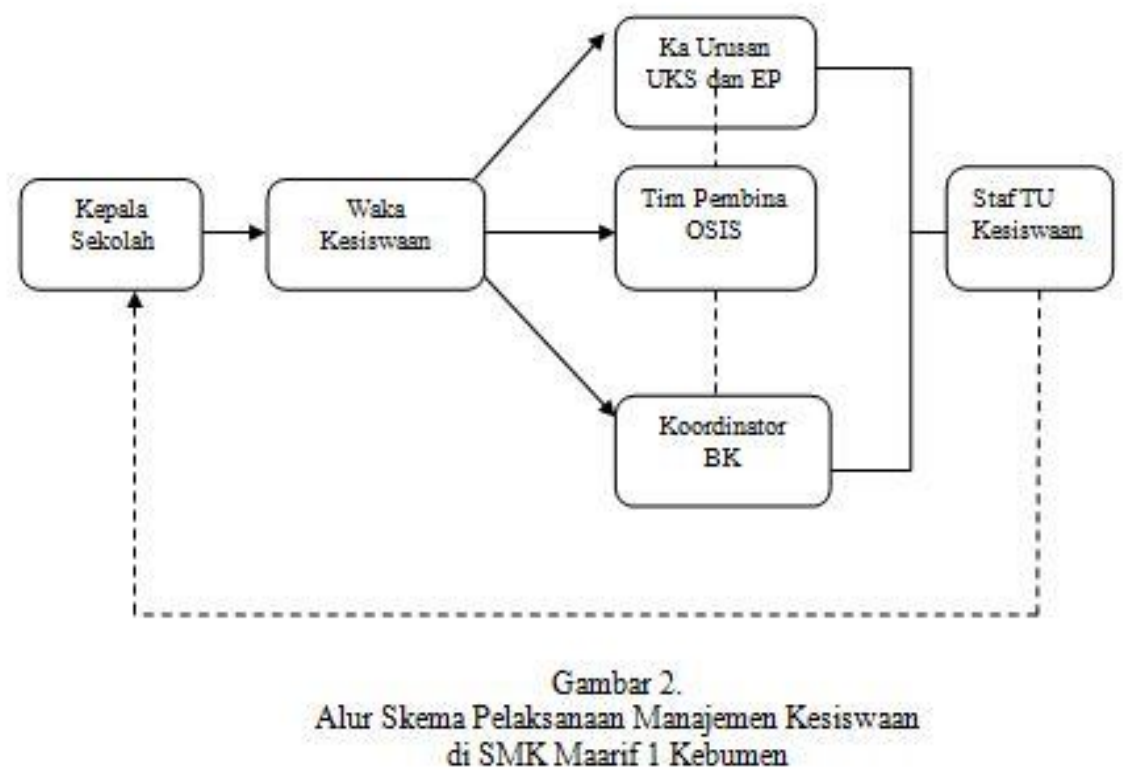

Dari skema di atas dapat diketahui bahwa pelaksaan manajemen peserta didik/kesiswaan dimulai dari monitoring Kepala Sekolah yang kemudian berkoordinasi dengan Wakil Kepala Bidang Kesiswaan, yang kemudian mendelegasikan tugas kepada Kepala Urusan UKS dan EP, Tim Pembina OSIS, dan Koordinator BK, dan kemudian akan dilanjutkan kepada staf TU Kesiswaan untuk keperluan pendataan secara rinci.

\section{Manajemen Pendidik dan Tenaga Pendidikan (Dik Tendik)}

\section{Deskripsi Administrasi Tenaga Pendidik dan Kependidikan}

Manajemen Dik Tendik ditangani oleh Wakil Kepala Sekolah Bidang Personalia. Sekolah ini memiliki 159 orang pendidik dan tenaga kependidikan, yang terdiri dari 121 guru dan 38 karyawan. Karyawan 38 orang terdiri dari 29 laki-laki dan 9 perempuan. Latar belakang pendidikan S1 7 orang, D3 5 orang, dan SMA/SMK 26 orang.

Dalam menjalankan tugas dan wewenangnya. Wakil Kepala Bidang Personalia dan staf mempunyai kebijakan yang dijadikan acuan untuk 
menjalankan tanggungjawabnya. Berikut skema pendelegasian tugas manajemen pendidk dan tenaga kependidikan SMK Ma'arif 1 Kebumen :

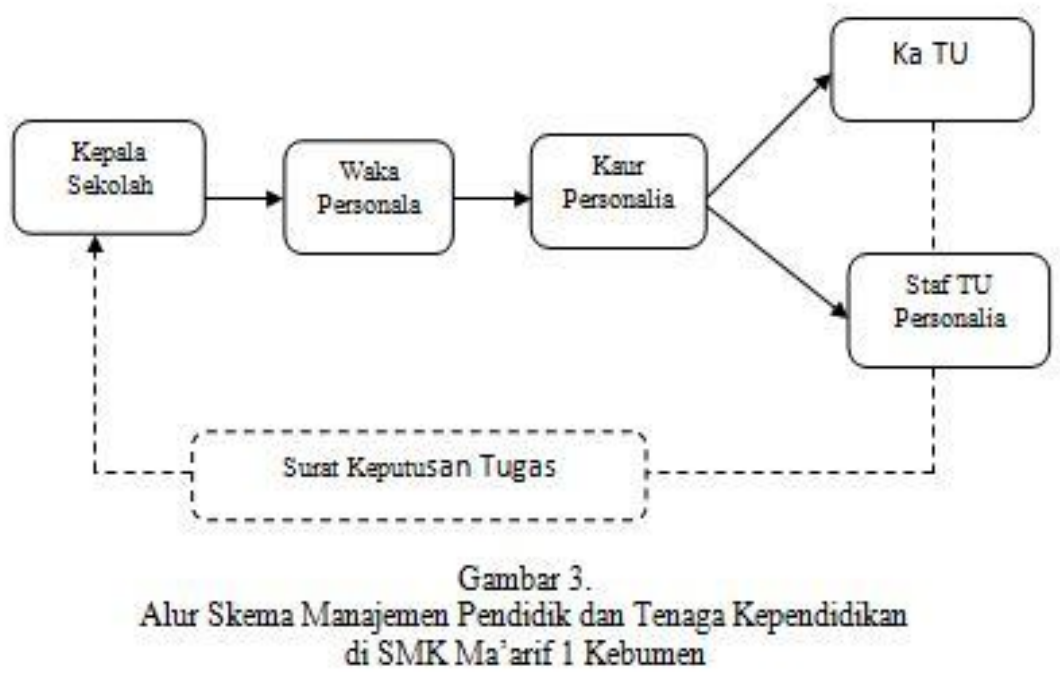

Maksud dari skema diatas adalah Kepala Sekolah sebagai center icon yang memonitoring manajemen, dan kemudian mendelegasikan tugas kepada Wakil Kepala Bidang Personalia, yang dilanjutkan penugasan kepada Kepala Urusan Personalia, dan kemudian kepada Kepala Tata Usaha yang berkoordinasi dengan staf TU Personalia. Produk personalia berupa sejumlah surat keputusan dan surat tugas bagi semua pendidik dan tenaga kependidikan.

Dalam mengemban amanahnya pendidik dan tenaga kependidikan mempunyai tanggungjawab terkait: (a)perencanaan sumberdaya manusia (SDM), (2)perekrutan tenaga pendidik dan tenaga kependidikan, (3)orientasi dan penempatan pendidik dan tenaga kependidikan, (4)pelatihan dan pengembangan, (5)penilaian dan pengawasan, (6)pemberian kompensasi, dan (7)pemberhentian.

\section{Manajemen Hubungan Industri dan Hubungan Masyarakat}

Hubungan Industri dalam sekolah kejuruan adalah hubungan yang di jalin oleh pihak sekolah dengan dunia industri maupun dunia usaha. Hubungan industri ini terjalin karena kedua belah pihak sama-sama memiliki kepentingan. Sekolah 
memiliki kepentingan untuk menyalurkan siswanya kedunia industri, dan industri memiliki kepentingan untuk mendapatkan tenaga kerja yang sesuai dengan kebutuhan dan kriteria yang ada di industri. Sedangkan hubungan masyarakat merupakan hubungan antara lembaga pendidikan dengan masyrakat. Salah satu peran humas dalam sekolah yaitu mengkomunikasikan kepentingan sekolah yang berhubungan dengan masyarakat dan juga mengenalkan sekolah ke lingkungan masyarakat.

Manajemen hubungan industri dan hubungan masyarakat dalam suatu sekolah dilaksanakan oleh wakil kepala sekolah bidang hubind dan humas. Salah satu tugas Wakasek Hubind dan Humas yaitu berusaha menjalin kerjasama dengan pihak industri dan masyarakat. Selain itu juga mengkomunikasikan segala kepentingan sekolah yang berkaitan dengan dunia industri dan duni usaha. Dalam melaksanakan tugasnya wakil kepala sekolah bidang hubungan industry dan masyarakat dibantu oleh beberapa staf yang ada. Di SMK Ma'arif 1 Kebumen wakil kepala sekolah bidang hub.ind dan humas, beliau Bapak Wawan Novianto, ST, M.Pd dalam melaksanakan tugasnya melibatkan beberapa pihak diantaranya staf waka, dunia usaha dan dunia industri (Du-Di), kepala jurusan, wali kelas, dan siswa sebagai objek pelaksanaan.

Program kerja hubungan industri dan hubungan masyarakat yaitu :

1. Memetakan minat siswa kelas XII

2. Merencanakan dan melaksanakan program kerja lapangan

3. Menjalin kerja sama dengan pihak industri yang sesuai dengan program keahlian yang ada di sekolah (link in match)

4. Menyediakan lapangan pekerjaan untuk lulusan SMK khususnya Ma' arif 1 melalui BKK

5. Membuat strategi pemasaran sekolah berbasis IT

6. Meningkatkan daya serap industri terhadap lulusan ma' arif.

Selain program kerja di atas, terdapat juga strategi dan pengembangan ketrampilan peserta didik salah satunya yaitu dengan mengadakan kegiatan Stir mobil yang bertujuan untuk meningkatkan daya tarik masyarakat terhadap 
sekolah. Terdapat juga beberapa program lainnya yaitu Praktik kerja Lapangan (PKL) dan Kunjungan Industri (KI). Praktik Kerja Lapangan (PKL) bertujuan untuk memberikan pelatihan ketrampilan yang sudah pelajari oleh siswa secara langsung. Kunjungan Industri (KI) ke wilayah Jabodetabek untuk kelas XI, yang bertujuan untuk meningkatkan motivasi belajar siswa dan supaya siswa dapat mengetahui dunia kerja secara langsung.

Adapun kerjasama yang telah di jalin sekolah dengan dunia industri di antaranya yaitu dengan Hitachi, Yamaha, FUSO Mitsubishi, Astra Honda Motor (AHM), Toyoseal dan masih banyak lagi.

Berikut skema pendelegasian tugas manajemen Hubungan Industri dan Masyarakat SMK Ma'arif 1 Kebumen:

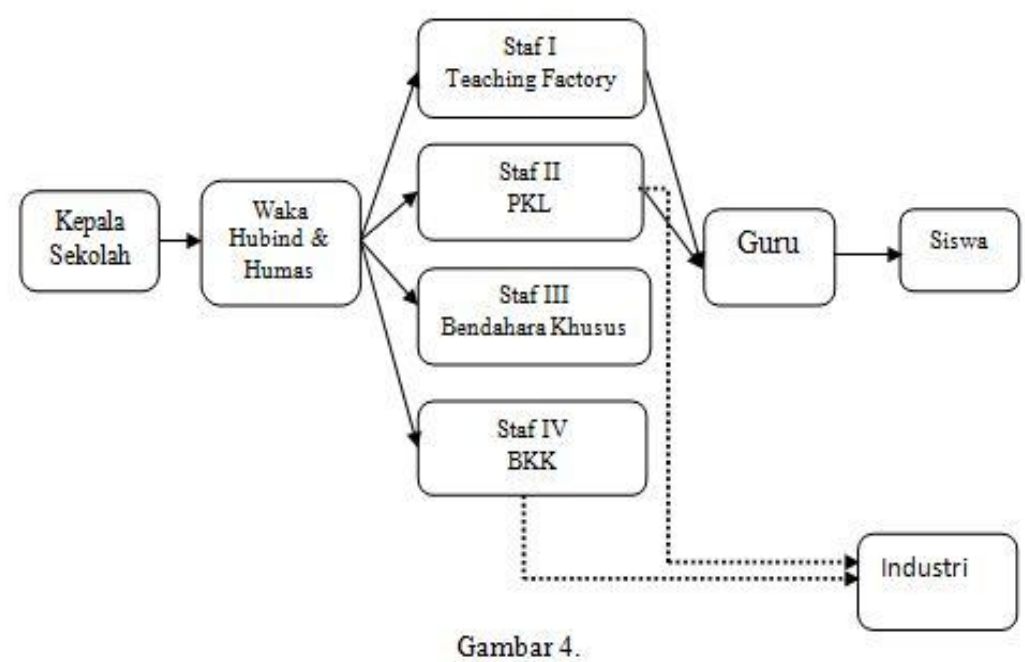

Alur Skema Manajemen Hubungan Industri dan Hubungan Masyarakat

Hubungan industri dan hubungan masyarakat di SMK Ma'arif 1 Kebumen, tidak selalu berjalan dengan baik, terkadang juga terdapat complain atau masukan dari pihak industry yang menjadi mitra sekolah dalam hal Praktik Kerja Lapangan 
(PKL), mengenai masih belum sesuainya ketrampilan yang dimiliki oleh siswa dengan keinginan industri. Hal tersebut dikarenakan di SMK Ma'arif 1 Kebumen terdapat tiga gelombang Praktik Kerja Lapangan (PKL) yaitu, gelombang pertama adalah siswa kelas XI Semester gasal, gelombang kedua adalah siswa kelas XI semester genap, dan yang ketiga adalah siswa kelas XII semester gasal. Untuk siswa yang mendapat gelombang pertama memang ada beberapa yang masih dalam tahap pengenalan sehingga dalam hal praktik kerja lapangan masih kurang memahami.

Untuk mengatasi hal tersebut pihak hubungan industri dan masyarakat SMK Ma'arif 1 Kebumen terlebih dahulu memberikan penjelasan kepada pihak industri mengenai teknis Pelatihan Kerja Lapangan (PKL). Sedangkan untuk siswa, mereka memberikan bimbingan dan pembekalan yang terdiri dari soft skill dan hard skill. Sehingga siswa tidak hanya fokus pada penguasaan ketrampilan tetapi juga pada attitude atau sikap.

\section{Analisa SWOT}

\section{A. Manajemen Kurikulum dan Pembelajaran}

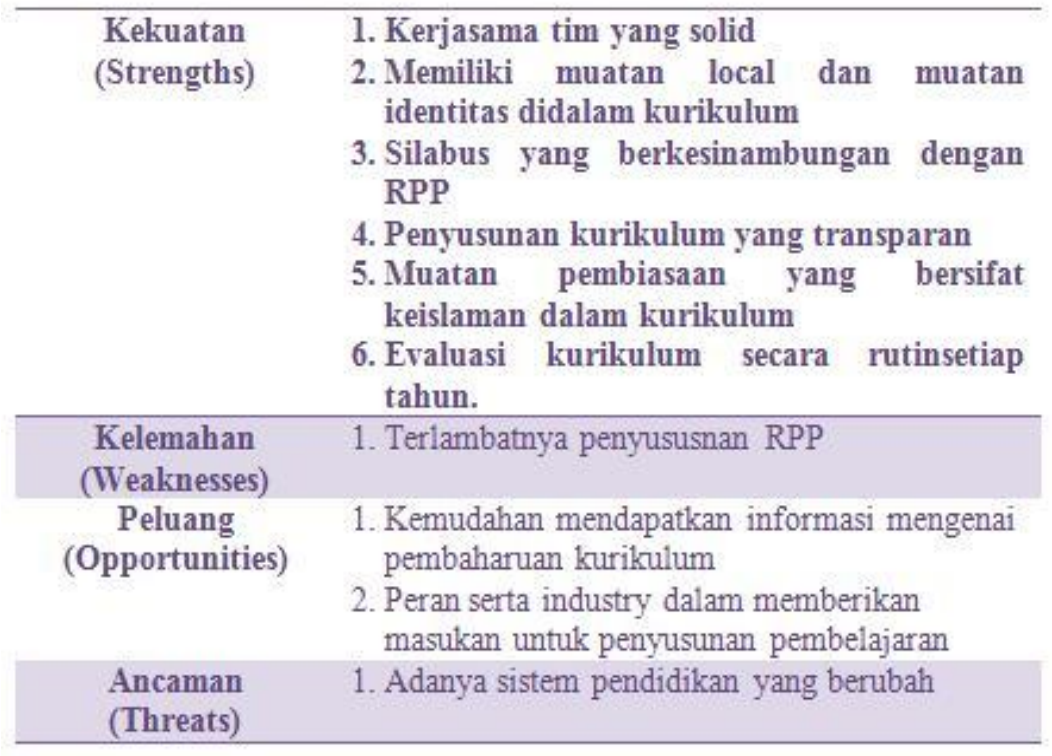


Dari analisa di atas dapat dilakukan empat strategi untuk meningkatkan mutu pendidikan dalam bidang kurikulum dan pembelajaran.

1. Strategi SO; menggunakan kekuatan dan memanfaatkan peluang.

Penyusunan kurikulum yang transparan, didukung dengan isi atau muatan kurikulum yang disesuaikan dengan lingkungan dan budaya sekolah, serta kerja sama tim yang solid menjadi kekuatan yang harus digunakan oleh SMK Ma'arif 1 kebumen dalam peningkatan manajemen kurikulum dan proses pembelajaran. Selain itu, silabus yang berkesinambungan dengan RPP dan evaluasi kurikulum yang dilakukan secara rutin, sehingga dapat diketahui tingkat keberhasilan dari pelaksanaan kurikulum di SMK Ma'arif 1 Kebumen.

Penggunaan kekuatan akan lebih berhasil ketika peluang juga dimanfaatkan. Peluang yang dimiliki SMK Ma'arif 1 Kebumen adalah kemudahan mendapatkan informasi, dalam hal ini berkaitan dengan kemudahan mendapatkan informasi tentang pembaharuan kurikulum, sehingga SMK Ma'arif 1 Kebumen dapat dengan mudah dan cepat mendapatkan informasi dan tidak tertinggal. Dalam hal penyusunan kurikulum pihak SMK Ma'arif 1 Kebumen mengikutsertakan pihak Dunia Usaha dan Dunia Industri (DUDI) sebagai mitra sekolah untuk memberikan masukan terkait kompetensi yang dibutuhkan oleh DUDI sekarang, sehingga sekolah dapat menyusun kurikulum yang selaras dengan kebutuhan pasar. Dengan memadukan dua unsur kekuatan dan peluang SMK Ma'arif 1 Kebumen dapat terus meningkatkan, dan memperbaiki serta mengembangkan kurikulum yang ada, sehingga dapat menyusun isi maupun proses pembelajaran yang unggul.

2. Strategi WO; memperbaiki kelemahan dan memanfaatan peluang

Selain strategi menggunakan kekuatan dan memanfaatkan peluang, terdapat juga strategi WO, yaitu memperbaiki kelemahan dan memanfaatkan peluang. Kelemahan terkait manajemen kurikulum dan pembelajaran di SMK Ma'arif 1 Kebumen menurut analisa SWOT diatas adalah terlambatnya penyususnan RPP oleh guru. Hal tersebut sudah berusaha ditangani oleh pihak 
wakil kepala sekolah bidang kurikulum dengan memberikan deat line untuk guru mengumpulkan RPP.

Selain itu perlu adanya pemanfaatan peluang untuk menekan kelemahan. Kemudahan mendapatkan informasi sebenarnya dapat dijadikan sebagai penekan kelemahan, sebab kemudahan mendapatkan informasi bagi guru akan memudahkan guru dalam menyusun dan menyelesaikan RPP, sehingga pengumpulan RPP tidak akan terlambat lagi.

\section{Strategi ST; menggunakan kekuatan dan menghindari ancaman}

Kerjasama tim yang solid dalam hal penyusunan kurikulum memudahkan pengembangan kurikulum yang sesuai dengan keadaan dan budaya sekolah, membuat penyusunan kurikulum yang transparan, serta evaluasi kurikulum yang dilakukan secara rutin setiap tahunnya. Hal tersebut dapat menekan dan mengatasi adanya sistem pendidikan yang sering kali berubah.

\section{Strategi WT; mengatasi kelemahan dan menghindari ancaman}

Keterlambatan penyususnan RPP oleh guru, merupakan hal yang harus di perbaiki sehingga proses pembelajaran dapat berjalan dengan baik. Selain itu perlu adanya antisipasi terhadap kemungkinan adanya perubahan sistem pendidikan.

Dari deskripsi tabel di atas dapat diketahui kelemahan dan ancaman yang dihadapi oleh SMK Ma'arif 1 Kebumen dalam bidang kurikulum dan pembelajaran. Kelemahan tersebut adalah keterlambatan pengumpulan RPP oleh guru yang dapat diatasi dengan menanamkan rasa tanggungjawab dan disiplin kepada guru, dengan cara memberikan batas waktu pengumpulan RPP. Jika dalam batas waktu tersebut guru masih belum mengumpulkan RPP maka perlu adanya pemberian peringatan atau sanki kepada guru. Selain kelemahan terdapat juga ancaman bagi SMK Ma'arif 1 Kebumen yaitu, adanya perubahan sistem pendidikan. Untuk menghadapi ancaman tersebut perlu adanya sistem informasi yang baik di sekolah dan perlu adanya tim penyusun kurikulum yang berkompeten dan solid. 


\section{B. Manajemen Peserta Didik}

\begin{tabular}{|c|c|}
\hline $\begin{array}{l}\text { Kekuatan } \\
\text { (Strengths) }\end{array}$ & $\begin{array}{l}\text { 1. Adanya monitoring dari kepala sekolah } \\
\text { secara berkala } \\
\text { 2. Adanya sinergi antara waka kesiswaan dan } \\
\text { waka diktendik } \\
\text { 3. Mengimplementasikan evaluasi kesiswaan } \\
\text { secara rutin dalam proses belajar mengajar } \\
\text { 4. Memiliki lulusan yang unggul dalam bidang } \\
\text { akademik dan non akademik }\end{array}$ \\
\hline $\begin{array}{c}\text { Kelemahan } \\
\text { (Weaknesses) }\end{array}$ & $\begin{array}{l}\text { 1. Kurangnya kedisiplinan anggota bidang } \\
\text { kesiswaan } \\
\text { 2. Kurangnya koordinasi antara waka kesiswaan } \\
\text { dan anggotanya } \\
\text { 3. Kurangnya ketegasan BK terkait tat tertib } \\
\text { sekolah sehingga siswa masih melakukan } \\
\text { kesalahan yang sama }\end{array}$ \\
\hline $\begin{array}{c}\text { Peluang } \\
\text { (Opportunities) }\end{array}$ & $\begin{array}{l}\text { 1. Menciptakan kesadaran religious dengan } \\
\text { menyediakan pondok pesantren bagi peserta } \\
\text { didik } \\
\text { 2. Dukungan dari orangtua yang tinggi }\end{array}$ \\
\hline Ancaman (Threats) & $\begin{array}{l}\text { 1. Adanya pembatasan jumlah rombel dari dinas } \\
\text { pendidikan wilayah } \\
\text { 2. Persaingan program keahlian dengan berbagai } \\
\text { lembaga pendidikan sejenis }\end{array}$ \\
\hline
\end{tabular}

Dari analisa di atas dapat dilakukan empat strategi untuk meningkatkan mutu pendidikan dalam bidang peserta didik.

1. Strategi SO; menggunakan kekuatan dan memanfaatkan peluang.

Berdasarkan analisa SWOT diatas dapat diketahui bahwa dalam proses manajemen peserta didik di SMK Ma'arif 1 Kebumen ditemukan beberapa kekuatan yang memicu tetap eksisnya SMK Ma'arif 1 Kebumen. Selain adanya kekuatan dalam proses manajemen peserta didik, ada pula peluang yang dapat dimanfaatkan untuk dapat lebih meningkatkan perkembangan dan kemajuan SMK Ma'arif 1 Kebumen.

Kekuatan dari suatu lembaga pendidikan sangat penting dalam meningkatkan kualitas untuk menuju kemajuan bagi lembaga pendidikan tersebut seperti yang diharapkan kepala sekolah bukan hanya sebagai center dalam lembaga pendidikan, tetapi Kepala Sekolah juga diharapkan dapat sebagai supervisor dan monitoring bagi semua peserta didik.

Misalnya, dalam strategi SO kepala sekolah bisa memanfaatkan peluang dengan kekuatan yang ada. Dengan menciptakan kesadaran religius bagi peserta 
didik serta mengoptimalkan dukungan dari orangtua dan meningkatkan kualitas pendidikan secara bertahap.

2. Strategi WO; memperbaiki kelemahan dan memanfaatan peluang

Kepala sekolah bisa menggunakan strategi WO dengan memperbaiki maupun meminimalisir kelemahan yang ada dengan memanfaatkan peluang. Misal dengan meminimalisir kedisiplinan staf anggota bidang kesiswaan dengan memperbaiki kebijakan dan jadwal yang lebih teratur.

Kelemahan dari Waka Kesiswaan kurangnya kedisplinan dalam mengatasi siswanya sehingga sekolah menyediakan pondok pesantren bagi peserta didik agar terciptanya kesadaran religius, dan bisa lebih bijak dalam menerapkan kebijakan sehingga staf anggota bidang kesiswaan mampu melaksanakan tugas dan tanggungjawab sebagaimana mestinya.

3. Strstegi ST; menggunakan kekuatan dan menghindari ancaman

Kepala sekolah bisa menggunakan strategi ST dengan memanfaatkan Kekuatan yang ada pada Lembaga Pendidikan SMK Ma'arif 1 Kebumen seperti memiliki lulusan yang unggul dalam bidang akademik dan non akademik melalui evaluasi secara rutin dalam proses belajar mengajar. Dan meminimalisir adanya ancaman seperti persaingan program keahlian yang sejenis di berbagai lembaga sehingga diharapkan lebih dalam mensiasati persaingan lembaga pendidikan sejenisnya dengan memanfaatkan sinergi antar unit dan kepala sekolah.

4. Strategi WT; mengatasi kelemahan dan menghindari ancaman

Kelemahan dari waka kesiswaan kurangnya koordinasi antara waka dengan anggotanya dengan melihat ancaman persaingan berbagai program keahlian yang ada pada SMK Ma'arif 1 Kebumen dengan lembaga pendidikan lainnya. Diharapkan mampu dijadikan sebagai motivasi dan antisipasi dalam mempertahankan eksistensi sekolah. 
Dari pemaparan analisa SWOT manajemen peserta didik di atas, dapat direkomendasikan bahwa Kepala Sekolah dapat menggunakan strategi WT dengan memperbaiki permasalahan supervisi dan memonitoring semua pihak yang terlibat dalam manajemen peserta didik agar tetap bersaing diantara lembaga pendidikan SMK sejenisnya.

\section{Manajemen Pendidik dan Tenaga Kependidikan}

\begin{tabular}{|c|c|}
\hline Kekuatan (Strengths) & $\begin{array}{l}\text { 1. Jumlah diktendik yang memenuhi standar } \\
\text { pendidikan } \\
\text { 2. Kompetensi diktendik sudah memenuhi } \\
\text { standar } \\
\text { 3. Peningkatan profesionalitas guru melalui } \\
\text { kegiata pengembangan profesi } \\
\text { 4. Adanya kompensasi sebagai motivasi bagi } \\
\text { diktendik. }\end{array}$ \\
\hline $\begin{array}{l}\text { Kelemahan } \\
\text { (Weaknesses) }\end{array}$ & $\begin{array}{l}\text { 1. Pelaksanaan rapat yang belum terkoordinasi } \\
\text { secara teratur } \\
\text { 2. Pendistribusian surat kepada diktendik yang } \\
\text { kurang efektif } \\
\text { 3. Laporan LPJ diktendik yang tidak tepat waktu }\end{array}$ \\
\hline $\begin{array}{c}\text { Peluang } \\
\text { (Opportunities) }\end{array}$ & $\begin{array}{l}\text { 1. Adanya forum ilmiah bagi pendidik } \\
\text { 2. Banyaknya seminar dan workshop tentang } \\
\text { pengembangan tenaga kependidikan }\end{array}$ \\
\hline Ancaman (Threats) & 1. Banyaknya tenaga pendidik yang masih muda \\
\hline
\end{tabular}

Dari analisa di atas dapat dilakukan empat strategi untuk meningkatkan mutu pendidikan dalam bidang pendidik dan tenaga kependidikan.

1. Strategi SO; menggunakan kekuatan dan memanfaatkan peluang.

Berdasarkan analisa SWOT diatas dapat diketahui bahwa dalam proses manajemen pendidik dan tenaga kependidikan di SMK Ma'arif 1 Kebumen ditemukan beberapa kekuatan yang memicu tetap eksisnya SMK Ma'arif 1 Kebumen. Selain adanya kekuatan dalam proses manajemen pendidik dan tenaga kependidikan, ada pula peluang yang dapat dimanfaatkan untuk dapat lebih meningkatkan perkembangan dan kemajuan SMK Ma'arif 1 Kebumen.

Kekuatan yang ada pada pendidik dan tenaga kependidikan yang memenuhi kompetensi standar pendidikan, dengan banyaknya jumlah pendidik dan tenaga kependidikan diharapkan mampu meningkatkan kompetensi pendidik dan tenaga kependidikan dibidangnya. Sehingga adanya peluang pendidik dan 
tenaga kependidikan yang dapat diikutsertakan dalam bebagai macam kegiatan pengembangan profesi seperti forum ilmiah, seminar, diklat dan workshop.

Misalnya, kepala sekolah dapat memanfaatkan strategi SO dengan cara menggunakan kekuatan dengan memanfaatkan peluang. Semisal, mempertahankan eksistensi dan kualitas mutu mengajar dengan mengaikutsertakan pendidik dan tenaga kependidikan di berbagai forum ilmiah yang diselenggarakan setiap tahunnya.

2. Strategi WO; memperbaiki kelemahan dan memanfaatan peluang

Berdasarkan analisa SWOT di atas dapat dipaparkan, dalam mengatasi problem tersebut. Kepala sekolah dapat melihat kelemahan pada pendidik dan tenaga kependidikan pelaksanaan rapat yang belum terkoordinasi secara teratur sehingga laporan LPJ yang tidak tepat waktu. Sehingga kepala sekolah bisa kembali menata pendidik dan tenaga kependidikan yang masih muda ataupun baru mengabdi di SMK Ma'arif 1 Kebumen dengan memanfaatkan peluang dengan mengembangkan profesi dan menggali skill dengan berbagai mengikutsertakan pada forum ilmiah maupun motivasi kerja demi meningkatkan loyalitas pendidik dan tenaga kependidikan dan etos kerja.

3. Strstegi ST; menggunakan kekuatan dan menghindari ancaman

Berdasarkan analisa SWOT di atas dapat diketahui bahwa kepala sekolah dapat memanfaatkan strategi ST yaitu dengan memanfaatkan kekuatan yang dimiliki pendidik dan tenaga kependidikan adanya peningkatan profesionalitas guru melalui pengembangan profesi dalam meningkatkan mutu pendidikan, sebagai motivasi bagi pendidik dan tenaga kependidikan. Diharapkan dapat mempertahankan eksistensinya meskipun persaingan dengan generasi penerus begitu ketat.

4. Strategi WT; mengatasi kelemahan dan menghindari ancaman

Melihat Kelemahan yang ada pada pendidik dan tenaga kependidikan pendistribusian surat yang kurang efektif sehingga dalam pembuatan laporan yang 
tidak teratur. Dengan melihat berbagai kelemahan dan ancaman yang ada pada SMK Ma'arif 1 Kebumen. Diharapkan mampu dijadikan sebagai acuan dalam profesionalitas kerja.

Dengan adanya analisa SWOT Manajemen Pendidik dan Tenagan Kependidikan di atas dapat direkomendasikan bahwa sangat dibutuhkan peran aktif dan sinergi dari kepala sekolah dan waka pendidik dan tenaga kependidikan serta stafnya dalam proses peningkatan mutu pendidikan harus memiliki komitmen etos kerja sebagai bentuk rasa dedikasi yang tinggi.

\section{Manajemen Hubungan Industri dan Hubungan Masyarakat}

\begin{tabular}{|c|c|}
\hline Kekuatan (Strengths) & $\begin{array}{l}\text { 1. Memiliki perencanaan program yang matang. } \\
\text { 2. Bekerja sama dengan berbagai DUDI yang } \\
\text { relevan }\end{array}$ \\
\hline $\begin{array}{c}\text { Kelemahan } \\
\text { (Weaknesses) }\end{array}$ & $\begin{array}{l}\text { 1. Pihak humas dan hubind belummampu } \\
\text { memberikan pemahaman mengenaijenjang } \\
\text { keahliankepada semua DUDI } \\
\text { 2. Belum a danya tenaga ahliyang focus menangani } \\
\text { kegiatan pemasaran }\end{array}$ \\
\hline Peluang (Opportunities) & $\begin{array}{l}\text { 1. Strategipemasaran yangkreatif daninovatif } \\
\text { mampumeringkatkananimo masyarakat } \\
\text { 2. Sistem informasi yangbaik }\end{array}$ \\
\hline Ancaman (Threats) & $\begin{array}{l}\text { 1. Tidak semua pihak industry memahamijenjang } \\
\text { keahlian diSMK } \\
\text { 2. Kriteria DUDI yang tinggi }\end{array}$ \\
\hline
\end{tabular}

Dari analisa di atas dapat dilakukan empat strategi untuk meningkatkan mutu pendidikan di bidang Hub-Ind dan Humas :

1. Strategi SO; menggunakan kekuatan dan memanfaatkan peluang. 
Dalam bidang Hubungan Industri dan Hubungan Masyarakat (Hubind) pastilah memiliki kekuatan dalam meningkatkan hubungan baik antara pihak sekolah dengan dunia usaha dan dunia industry (DUDI). Kekuatan yang di miliki bidang Hubind diantaranya, perencanaan program yang matang. Dengan perencanaan program yang matang akan berdampak dalam pelaksanaan program. Selain itu, adanya kerja sama dengan berbagai dunia usaha dan dunia industry yang relevan menjadikan sebuah kekuatan yang dimiliki sekolah. Terjalinya hubungan baik dengan dunia usaha dan dunia industry akan menciptakan kepercayaan anatara DUDI dengan sekolah.

Peluang juga memiliki keterkaitan dengan kekuatan. Dengan kekuatan, maka akan tercipta sebuah peluang. Dari kekuatan yang di miliki oleh SMK Ma'arif 1 Kebumen memudahkan dalam menciptakan strategi pemasaran sekolah karena seklah sudah memiliki keunggulan. Strategi pemasaran yang kreatif dan inovatif mampu meningkatkan animo masyarakat terhadap SMK Ma'arif 1 Kebumen. Selain itu, dengan system informasi yang baik memudahkan dalam pelaksanaan sebuah program yang sudah terencana.

2. Strategi WO; memperbaiki kelemahan dan memanfaatan peluang Strategi ini memperbaiki kelemahan yang ada pada bidang Hubungan Industri dan Hubungan Masyarakat serta memanfaatkan peluang yang ada. Kelemahan yang ada di bidang Hub-Ind yaitu, Pihak humas dan hub-ind belum mampu memberikan pemahaman mengenai jenjang keahlian kepada semua DUDI. Kelemahan lainya, belum adanya tenaga ahli yang focus menangani kegiatan pemasaran.

Kelemahan harus di perbaiki dengan memanfaatkan peluang yang ada. Peluang dalam bidang Hubungan Industri dan Hubungan Masyarakat yaitu terkait dengan strategi pemasaran yang kreatif dan inovatif mampu meningkatkan animo masyarakat. Selain itu, peluang lain yaitu mengenai system informasi yang baik yang ada di dalam bidang HubInd.

3. Strategi ST; menggunakan kekuatan dan menghindari ancaman 
Strategi ini menggunakan kekuatan serta menghindari ancaman yang ada di SMK Ma'arif 1 Kebumen. Dengan perencanaan program yang matang dan bekerja sama dengan berbagai DUDI yang relevan, maka menjadi sebuah kekuatan dalam meningkatkan manajemen sekolah dalam bidang Hub-Ind.

Ancaman dalam bidang hub-in yaitu, tidak semua pihak industry memahami jenjang keahlian keahlian di SMK. Selain itu juga kriteria DUDI yang tinggi mengharuskan sekolah untuk selalu memperbaharui pembelajaran sesuai dengan kebutuhan industri. Dengan sebuah kekuatan akan meminimalisir sebuah ancaman.

4. Strategi WT; mengatasi kelemahan dan menghindari ancaman

Strategi ini mengatasi kelemahan serta menghindari ancaman. Kelemahan menjadi sesuatu yang harus di minimalisir, di atasi, dan di perbaiki supaya tidak menjadi ancaman di kemudian hari. Kelemahannya, pihak humas dan hub-ind belum mampu memberikan pemahaman mengenai jenjang keahlian kepada semua DUDI dan belum adanya tenaga ahli yang focus menangani kegiatan pemasaran.

Ketika terdapat kelemahan maka akan terdapat juga ancaman. Ancaman yang ada yaitu, tidak semua pihak industry memahami jenjang keahlian di SMK dan kriteria DUDI yang tinggi. Ancaman ini harus di hindari serta kelemahan juga harus di perbaiki agar tidak terjadi hal-hal yang tidak di inginkan.

Dari hasil analisa di atas, dapat dilihat kekuatan, kelemahan, peluang dan ancaman yang dimiliki SMK Ma'arif 1 Kebumen dibidang hubungan industry dan hubungan masyarakat. Analisa tersebut dapat dijadikan pertimbangan bagi pihak sekolah dalam mengelola bidang hubungan industry dan hubungan masyarakat. Memanfaatkan peluang dan nengoptimalkan kekuatan merupakan hal yang harus dilakukanoleh sekolah, disisi lain perlu adanya penekanan pada ancaman dan penyelesaian pada kelemahan.

Bidang hubungan industri dan hubungan masyarakat SMK Ma'arif 1 Kebumen harus mampu menjelaskan kepada seluruh pihak industry yang bekerja sama dengan sekolah mengenai jenjang keahlian yang ada di sekolah dengan cara 
memberikan pengarahan dan sosialisasi kepada DUDI terkait hal tersebut, sehingga nantinya tidak ada kesalah pahaman diantara sekolah dan DUDI.

Selain mengurusi hubungan industry, hubin dan humas juga berperan sebagai marketing sekolah. Sebagai marketing sekolah perlu adanya strategi yang efektif dan efisien sehingga dapat menggiring opini masyarakat terhadap sekolah. Dalam hal ini perlu adanya tenaga ahli yang fokus menanganinya.

\section{Kesimpulan}

Manajemen pendidikan di SMK Ma'arif 1 Kebumen sudah memenuhi standar pendidikan nasional baik dari perencanaan, pengorganisasian pelaksanaan dan evaluasinya. Kurikulum yang diterapkan di SMK Ma'arif 1 Kebumen merupakan kurikulum tingkat satuan pendidikan tahun 2013, yang disusun berdasarkan peraturan pemerintah dan disesuaikan dengan budaya dan lingkungan sekolah. Dalam proses manajemen pendidikan di SMK Ma'arif 1 Kebumen, pemicu sekolah tetap dapat eksis hingga kini bukanlah hanya manajemen kurikulumnya yang saja yang berkualitas tetapi manajemen kesiswaanya pun tidak dapat diragukan lagi. Dengan dibuktikannya kurun lima tahun terakhir ini sekolah tersebut mampu mendongkrak popularitas. Terbukti dengan meningkatnya jumlah peserta didik setiap tahunnya. Bukan hanya itu saja, tetapi semua out come dapat diserap oleh DUDI di Batam. Keunggulan SMK Ma'arif 1 Kebumen tak lepas dari peran Bapak Subchan, S.SOS.I.M.Pd selaku kepala sekolah yang ikut andil dalam kemajuan sekolah. Kepala sekolah tidak segan untuk turun langsung memonitoring maupun menyuvervisi semua unit termasuk bidang kesiswaan dan personalia. Dalam proses manajemen pendidik dan tenaga kependidikan,kepala sekolah selalu mengedepankan loyalitas dalam membentuk pendidik dan tenaga kependidikan yang profesional dan beretika. Kepala sekolah selalu mengupayakan yang terbaik untuk pendidik dan tenaga kependidikannya dengan menggali skill dan mengembangkan keahlian demi memupuk rasa etos dan loyalitas kerja yang tinggi. Semisal dengan mengikutsertakan mereka pada forum ilmiah sebagai bentuk pengembangan profesi. Selain tiga manajemen di atas, dalam Sekolah Kejuruan terdapat bidang yang mengurusi hubungan industri 
dan hubungan masyarakat. Proses manajemen bidang hubungan industri dan masyarakat sudah terlaksana dengan baik. Semua program sudah di analisis berdasarkan analisis SWOT. Melalui bidang hubind dan humas ini sekolah juga telah melakukan kerja sama yang baik dengan berbagai bidang industri yang relevan dengan kompetensi keahlian yang ada di SMK Ma'arif 1 Kebumen.

Dalam manajemen kurikulum dan pembelajaran, keterlambatan pengumpulan RPP oleh guru yang dapat diatasi dengan menanamkan rasa tanggungjawab dan disiplin kepada guru, dengan cara memberikan batas waktu pengumpulan RPP. Jika dalam batas waktu tersebut guru masih belum mengumpulkan RPP maka perlu adanya pemberian peringatan atau sanki kepada guru. Selain itu, untuk menghadapi adanya perubahan sistem pendidikan di perlukan adanya sistem informasi yang baik di sekolah dan perlu adanya tim penyusun kurikulum yang berkompeten dan solid. Melihat kendala yang dihadapi manajemen peserta didik di atas, dapat direkomendasikan bahwa Kepala Sekolah dapat menggunakan strategi WT dengan memperbaiki permasalahan supervisi dan memonitoring semua pihak yang terlibat dalam manajemen peserta didik agar tetap bersaing diantara lembaga pendidikan SMK sejenisnya. Sedangkan untuk mengatasi kendala dalam Manajemen Pendidik dan Tenaga Kependidikan di atas dapat direkomendasikan bahwa sangat dibutuhkan peran aktif dan sinergi dari kepala sekolah dan waka pendidik dan tenaga kependidikan serta stafnya dalam proses peningkatan mutu pendidikan harus memiliki komitmen etos kerja sebagai bentuk rasa dedikasi yang tinggi. Berdasarkan hasil analisa SWOT pada bab sebelumnya, Bidang hubungan industri dan hubungan masyarakat SMK Ma'arif 1 Kebumen harus mampu menjelaskan kepada seluruh pihak industry yang bekerja sama dengan sekolah mengenai jenjang keahlian yang ada di sekolah dengan cara memberikan pengarahan dan sosialisasi kepada DUDI terkait hal tersebut, sehingga nantinya tidak ada kesalah pahaman diantara sekolah dan DUDI. Selain mengurusi hubungan industry, hubin dan humas juga berperan sebagai marketing sekolah. Sebagai marketing sekolah perlu adanya strategi yang efektif dan efisien sehingga dapat menggiring opini masyarakat terhadap sekolah. Dalam hal ini perlu adanya tenaga ahli yang fokus menanganinya. 


\section{Daftar Pustaka}

Agus Salim Chamidi dan Tutik Rodhiana, 2018. "Upaya Penguatan Manajemen Pendidikan Baca Tulis Al-Qur'an (BTQ) Studi Kasus di Sekolah Dasar Negeri 1 Kutowinangun", Jurnal Cakrawala, Volume 2, Nomor 1, Tahun 2018

Albi Anggito dan Johan Setiawan.2018.Metode Penelitian Kualitatif.Cet.1Sukabumi: CV. Jejak.

David Wijaya, 2009. "Manajemen Sumber Daya Manusia Penedidikan Berbasis Kompetensi Guru dalam Rangka Membangun Keunggulan Bersaing Sekolah", Jurnal Pendidikan Penabur, Nomor 12,Tahun ke-8, Juni 2009

Engkoswara dan Aan Komariyah. 2011. Administrasi Pendidikan. Bandung: Alfabeta

Iskandar Putong, 2003. "Teknik Pemanfaatan Analisis SWOT Tanpa Skala Industri”, Jurnal Ekonomi dan Bisnis, Nomor 2, Jilid 8, Tahun 2003

Luki Eko Cahyono, Satrijo Budiwibowo, Juli Murwani, 2015. "Analisis penerapan 8 Standar Nasional Pendidikan pada SMP Negeri 2 Dolopo Kabupaten Madiun", Jurnal Assets, Volume 4, Nomor 2, Oktober 2015Mahmud. 2011.Metode Penelitian Pendidikan.Bandung: CV. Pustaka Setia.

Muwahid Shulhan dan Soim. 2013. Manajemen Pendidikan Islam. Yogyakarta: Teras

Nur Kholis. 2014. Manajemen Strategi Pendidikan. Cet.1. Surabaya: CV. Cahaya Intan XII

Peraturan Menteri Pendidikan dan Kebudayaan RI Nomor 34 Tahun 2018 tentang Standar Nasional Pendidikan Sekolah Menengah Kejuruan/Madrasah Aliyah Kejuruan

Siti Farikhah. 2015. Manajemen Lembaga Pendidikan. Yogyakarta : Aswaja Pressindo.

Sugiyono. 2015.Metode Penelitian Pendidikan.Bandung: Alvabeta. 
Syaifudin Sagala. Manajemen Strategi Dalam Peningkatan Mutu Pendidikan.

(Bandung: Alfabeta). 2010, hal. 140

Syifudin Sagala. 2010. Manajemen Strategi Dalam Peningkatan Mutu Pendidikan. Bandung: Alfabeta

Undang Undang Nomor 20 Tahun 2003 tentang Sistem pendidikan Nasional 